\title{
62-Henry James'in Beast in the Jungle adlı kısa romanının Türkçeye yapılan çevirilerinin karşılaştırılması
}

\section{Harika KARAVIN YÜCE 1}

APA: Karavin Yüce, H. (2020). Henry James'in Beast in the Jungle adlı kısa romanının Türkçeye yapılan çevirilerinin karşılaştırılması. RumeliDE Dil ve Edebiyat Araştırmaları Dergisi, (21), 9911004. DOI: $10.29000 /$ rumelide. 843471.

\section{$\ddot{O} z$}

Edebi eserlerin farklı zamanlarda yeni çevirilerinin üretilmesi, bu eserlerin "yeniden çeviri" bağlamında ele alınmasını gerekli kılmaktadır. Yayın dünyasında önemli bir yere sahip olan yeniden çevirilerin incelenmesi edebi çevirilerin üretim ve alımlanma koşulları hakkında bilgi sunmaktadır. Söz konusu incelemeler çeviri kararlarının arkasında yatan nedenler üzerine de yoğunlaştığından çeviri eleştirilerinin nesnelliğine katkıda bulunmaktadır. Buradan hareketle, çalışmada Henry James’in 1903 yılında kaleme aldığı Beast in the Jungle kısa romanın Türkçeye yapılan iki çevirisi üzerinden nesnel bir çeviri eleştirisi sunulması amaçlanmıştır. Çevirmen davranışlarının belirlenmesinde betimleyici yaklaşım temel alınıp, kaynak ve erek metinler arasındaki ilişkiler dilsel, biçemsel ve anlamsal düzlemde ele alınmıştır. Bu bağlamda, metinlerin aktarımında karşılaşılan dilsel, biçemsel ve anlamsal sorunlar üzerinde durulmuştur. Öte yandan, çeviri kararlarını etkileyen metin ötesi unsurları açığa çıkarmak amacıyla çalışmanın birinci bölümünde yazar ve biçemi hakkında bilgi verilip, hikayenin kısa özeti sunulmuştur. İkinci bölümde kaynak ve erek metinler arasındaki ilişkiler betimlenip, metinlerin birbirinden farklılaştığı noktalar saptanmıştır. Diğer ifadeyle, metinlerden seçilen örneklerle çevirmenlerin kaynak metni hangi noktalarda farklı okudukları, anladıkları ve yorumladıkları gösterilmeye çalışılmıştır. Farklılığın gözlemlendiği noktalarda çevirmenlerin aldığı kararlar ve bu kararların olası nedenleriyle ilgili varsayımlar üretilmiştir. Çalışmanın son bölümünde ise, oluşturulan varsayımlar üzerinden çevirmen davranışlarıyla ilgili bazı gözlemlerde bulunulmuştur. Ayrıntılı incelemeler sonucunda çevirmenlerin kaynak metni farklı şekilde okudukları ve yorumladıkları sonucuna varılmıştır.

Anahtar kelimeler: Çeviri eleştirisi, yeniden çeviriler, betimleyici yaklaşım, çeviri kararları

\section{A comparison of Turkish translations of Henry James' short novel Beast in the Jungle}

\begin{abstract}
Production of new translations of literary works at different times makes it necessary to deal with these works within the framework of "re-translation". Analysis of re-translations that have a significant place in publishing industry provides information regarding production and reception of literary translations. Since such analyses also focus on the reasons behind translation decisions, they contribute to the objectivity of translation criticisms. Thus, this study aims to present an objective translation criticism through two Turkish translations of the short novel, Beast in the Jungle, written by Henry James in 1903. In order to identify translator behaviors, descriptive approach was adopted, and the relations between the source and target texts was examined on linguistic, stylistic and semantic level. In this context, the linguistic, stylistic and semantic problems

Dr., Bağımsız Araştırmacı (İstanbul, Türkiye), harika.karavin@gmail.com, ORCID ID: oooo-0oo1-5113-4808 [Araştırma makalesi, Makale kayıt tarihi: 19.11.2020-kabul tarihi: 17.12.2020; DOI: 10.2900o/rumelide.843471]

Adres


observed in the transfer of the texts were touched upon. On the other hand, in the first part of the study, some information about the author, his style and the synopsis was given with the aim of revealing the extra-textual elements that affected translation decisions. In the second part, the relations between the source and target text were described, and the observed divergences between them was identified. To put it differently, with the selected examples from the texts, it was aimed to show at which points the translators read, understand and interpret the text differently. For the divergences, some assumptions regarding translation decisions and their probable reasons were provided. In the last part of the study, based on these assumptions, some observations for the translator behaviors were made. As a result of the detailed analyses, it was concluded that the translators read and interpreted the source texts in a different way.

Keywords: Translation criticism, re-translations, descriptive approach, translation decisions

\section{Giriş}

Geçmişten bu yana yeniden çeviriler yayın dünyasında önemli bir yere sahiptir. Çeviri eserler çeşitli nedenlerle farklı ya da aynı dönemlerde yeniden çevrilmektedir. Genellikle belli bir ideolojik çabanın ürünü olan yeniden çeviriler kimi zaman da kişisel tercihlerin sonucu üretilmektedir. Çevirmenler kaynak metinleri erek dilde farklı bir yorumlamayla sunmakta ve böylece aynı kaynak metnin farklı çevirileri ortaya çıkmaktadır. Söz konusu yeniden çevirilerin gerekliliği üzerine kuramcılar çeşitli savlarda bulunmuşladır. Önemli kuramcılardan Antoine Berman'a göre, dilin eskimesi nedeniyle kaynak metinlerin yaşlanması yeniden çevirilerin oluşmasına zemin hazırlamıştır (1990: 1). Diğer taraftan Lawrence Venuti, kaynak metne farklı bir yorum getirmek için yapılan yeniden çevirilere çoğunlukla kaynak metin "yetersiz" bulunduğunda başvurulduğunu belirtmiştir (2013: 97). Bu nedenle, yeniden çevirilerden çevrildiği dönemin dil, kültür ve edebi normlarını yansıtması ve erek kültüre daha önce yapılan çeviriden daha "başarılı" bir eser sunmaları beklenmiştir. Yeniden çevirilerin incelenmesi çeviri eleştirisi açısından da önemli bir çalışma alanı oluşturmaktadır. Yeniden çevirileri incelerken aynı ya da farklı dönemlerde çeviri yapmış öznenin çeviri davranışlarını gözlemleme ve karşılaştırma olanağı elde edebiliriz. Bunun yanı sıra, yeniden çeviriler okura belli bir dönemde egemen olan toplumsal, kültürel, tarihsel ve çeviri normlarına dair ipuçları sunabilir. Ayşe Ece'nin de belirttiği üzere, “çevirmenin yaratıcı bilişsel eyleminin izleri özellikle yeniden çeviri incelemelerinde görünürlük kazanır; çünkü iyi ya da daha fazla erek metin incelendiğinde kaynak metnin farklı yorumları ve farklı erek kullanımları bağlamında çevirmenlerin birbirlerinden ayrılan çeviri davranışları açı̆̆a çıkar” (2010: 48).

Bu çalışmada Henry James'in 1903 yılında kaleme aldığı Beast in the Jungle kısa romanın Türkçe'ye yapılan iki çevirisi incelenip çevirmen davranışları karşılaştırılacaktır. İncelenen iki çeviri de hala yayın dünyamızda yaşamını sürdürmektedir. Çevirilerden ilki (EM1) 1988 yılında Adam Yayınları tarafından "Ormandaki Canavar" adıyla basılmıştır. Adam Yayınları 1981 yllında kurulmuş olup, dünya klasikleri, edebi eserler ve çocuk kitapları basan bir yayınevidir. Bu çeviri Henry James çevirmeni olarak tanınan önemli çevirmen ve akademisyenlerden Necla Aytür (Ç1) tarafından yapılmıştır. Aytür, lisans ve doktora eğitimini İngiliz Dili ve Edebiyatı bölümünde tamamladıktan sonra üniversitelerde Amerikan edebiyatı dersleri vermeye başladı. Uzun yıllar kitap çevirisi yapan Aytür, Willian Faulkner’ı ilk kez Türk okuruyla tanıştırmıştır. Aytür'ün diğer eserleri Uyanış, Kate Chopin (1990, Adam); Henry James'in üç kısa romanından oluşan Yürek Burgusu (1988, Adam); Henry James'in Bir Kadının Portresi (2006, YKY) Ünal Aytür'le birlikte); ve William Faulkner'ın Çılgın Palmiyeler'dir (2011, YKY). Bunlara ilaveten Aytür çeşitli etnik gruplardan çağdaş kadın yazarların

\footnotetext{
Adres | Address

İstanbul Medeniyet Üniversitesi, Eğitim Bilimleri Fakültesi, Türkçe İstanbul Medeniyet University, Faculty of Education Sciences, ve Sosyal Bilimler Eğitimi Bölümü, Türkçe Eğitimi ABD Cevizli Turkish and Social Scinces Education, Turkish Language Teaching Kampüsü, Kartal-İstanbul/TÜRKIYE $\quad$ Education, Cevizli Campus, Kartal-İstanbul /TURKEY e-posta: editor@rumelide.com $\mid$ e-mail: editor@rumelide.com
} 
öykülerini derleyip Başka Bir Amerika (1999, Papirüs) adı altında yayımlatmıştır. İkinci çeviri (EM2) Altın Bilek Yayınları tarafından 2015 yılında Aslı Sena Özarpacı’nın (Ç2) çevirisiyle (Ormandaki Canavar) yayımlanmıştır. 2005 yılında kurulmuş olan bu yayınevi özellikle Türk ve dünya edebiyatı, popüler bilim, şiir, macera, polisiye, gerilim türünde kitaplar basmaktadır. Kitabın çevirmeni Özarpacı İstanbul Üniversitesi İngiliz Dili ve Edebiyatı bölümünde lisans ve yüksek lisans eğitimini tamamlamıştır. 2011 yılından beri Booking.com şirketinde dil uzmanı olarak görev yapan Özarpacı çeşitli yazarlardan kitaplar çevirmiştir: David Hawson'dan Ölüm Zamanı (2007, Altın Bilek), Thomas Hardy’den Ağaç İşçileri (2009, Altın Bilek), George Eliot’tan Düşürülen Maske (2011, İthaki) vb.

Çalışmada sunulacak çeviri eleştirisi denemesinde betimleyici yaklaşım temel alınıp, kaynak ve erek metinler arasındaki ilişkiler karşılaştırmalı bir şekilde incelenecektir. Çalışmanın birinci bölümünde yazar ve biçemi hakkında bilgi verilip, hikayenin kısa özeti sunulacaktır. İkinci bölümde kaynak ve erek metinler arasındaki ilişkiler betimlenip, metinlerin birbirinden farklılaştığ 1 noktalar saptanacaktır. Farklılığın gözlemlendiği noktalarda çevirmenlerin aldığı kararlar ve bu kararların olası nedenleriyle ilgili varsayımlar üretilmeye çalışılacaktır. Çalışmanın son bölümünde ise oluşturulan varsayımlar üzerinden çevirmen davranışları ile ilgili bazı değerlendirmelerde bulunulacaktır.

\section{Yazar ve biçemi hakkında}

Edebiyat eleştirileri, romanları ve kısa hikayeleriyle döneminin en önemli yazarlarından biri olan Henry James 1843 yılında New York'ta doğmuştur. Zengin bir ailenin çocuğu olan James babası sayesinde daha küçük yaşlarda Ralph Waldo Emerson ve William Makepeace Thackeray gibi ünlü romancılarla tanışma firsatı elde etmiştir. On iki yaşında geldiğinde James ailesiyle birlikte Avrupa'ya seyahat etmiş, Paris ve Londra gibi çeşitli şehirleri gezmiştir. 1962 yılında Harvard Hukuk Okulu'nda öğrenim görmeye başlamış ancak kısa bir süre okulu terk etmiştir. Aslında James hukuktan ziyade edebiyata ilgili duyuyordu ve yazarlık kariyeri "A Tragedy of Horror" (Korkunun Trajedisi) adlı kısa öyküsünün basılmasıyla başlamıştı. Yazarlık kariyeri boyunca James toplamda on roman, on kısa roman, yüz yirmi öykü, dokuz oyun ve dört yüz elli makale kaleme almıştı. Eserlerinin çoğunda Avrupa'nın Amerikan toplumu üzerindeki etkisini işlemektedir (Anderson, 2004: 211). Daisy Miller adlı kısa romanıyla James edebiyat dünyasında adından söz ettirmeye başlamıştı. Yazarların kendi dünya görüşlerini açılkama özgürlüğüne sahip olmaları gerektiğini savunan James edebi eleştiriye önemli katkı sağlamıştır. James'e göre metinler her şeyden önce gerçekçi olmalı ve okurlara gerçek yaşamı yansıtmalıdır (s. 212). 1879 ve 1882 ylları arasında James, the Europeans, Washington Square, Confidence ve The Portrait of a Lady adlı romanlarını yazdı. James' in başarısı 1899 yllında sonra The Sacred Fount, the Wings of the Dove, the Ambassadors ve the Golden Bowl romanlariyla doruk noktasına ulaşmıştır. Birinci dünya şavaşı patlak verdikten sonra James çeşitli hastanelerde çalışmış, savaş yardım kuruluşları için yazılar yazmış ve Belçikalı mültecilere yardım etmiştir. Daha sonra Amerika'nın savaşa girmeme kararını protesto etmek için 1915 yılında İngiliz vatandaşı olmuştur. Bu yüzden kendisine 28 Şubat 1916 tarihinde Kral George tarafından liyakat nişanı verilmiştir. James 1911, 1912 ve 1916 ylllarında Edebiyat Nobel Ödülü’ne aday gösterilmiştir. ${ }^{2}$

Bilindiği üzere on dokuzuncu yüzyılın sonlarına doğru çağdaş roman yazımında "şiirsel" biçem yaygınlaşmaya başlamış ve metinlerde imge değişmeceli, sembolik dil ve şiire özgü diğer dilbilimsel yapıların kullanımı önemli ölçüde artmıştır (Patrick, 1967: 77). Bu biçemin önemli temsilcilerinden biri olan James romanlarında kullandığı karmaşık sözcüksel ve sözdizimsel biçimlerle eserlerinde psikolojik derinlik yaratmayı hedeflemiştir. Ormandaki Canavar adlı eserinde de görüldüğü üzere

\footnotetext{
2 http://www.nobelprize.org/nomination/archive/show_people.php?id=4537

Adres

İstanbul Medeniyet Üniversitesi, Eğitim Bilimleri Fakültesi, Türkçe ve Sosyal Bilimler Eğitimi Bölümü, Türkce Eğitimi ABD Cevizli Kampüsü, Kartal-İstanbul/TÜRKIYE e-posta: editor@rumelide.com

Address

İstanbul Medeniyet University, Faculty of Education Sciences,

Turkish and Social Scinces Education, Turkish Language Teaching

Education, Cevizli Campus, Kartal-İstanbul /TURKEY

e-mail: editor@rumelide.com
} 
James'in şiirsel biçemi içeriğinin ayrılmaz bir parçası haline gelmiştir. Bir çok eleştirmenin de belirttiği üzere, "Marcher'ın çekiciliği James'in hikayeyi anlatış tarzından kaynaklanmaktadır" (Goodheart, 2003: 118). Romanın neredeyse tamamında basit ve anlamı doğrudan veren cümleye rastlamak olanaksızdır. Bu nedenle James okurdan örtük ve karmaşık bir şekilde sunulan anlamı çözümlemesini beklemektedir diyebiliriz. Eugene Goodheart'ın da belirttiği gibi, romanı okuyanlar "romandaki eylemin dilin kendisinde gerçekleştiğini” kolayca fark edeceklerdir (a.g.e.). Romandaki sözdizimsel öğeler sayesinde okurlar karmaşıklık, tedirginlik, belirsizlik ve güven duygularını bir arada deneyimlerler. Örneğin, James asıl anlatmak istediği meseleyi cümlenin sonuna kadar açılamayarak okurun dikkati ve merakını canlı tutmaya çalışır (s. 119). Ayrıca James cümlelerinde sıkça ara söz kullanarak temel mesajı cümlenin sonuna kadar saklamayı tercih eder. What Maisie Knew romanına yazmış olduğu önsözde James romanlarındaki sahneleri nasıl düzenlediğini şu şekilde açılamaktadır: "Sahne düzenli olarak ritmik bir şekilde tekrarlar; ara ara gözlemlenen boşluklar, öğelerin farklı bir etki yaratmak için farklı bir kurala göre yan yana getirilmesi başka bir şeye hazırlık niteliğindedir, tıpkı sahneye ait öğelerin belli bir temsile hizmet etmesi gibi”3 (1897: 2). Bu nedenle, içeriğin bir bütün halinde sunulması okurun mesajı yakalayabilmesi için zihinsel bir çaba gerektirmektedir. Sonuç olarak, romandaki karakterlerle ilgi bilgiye yazarın bilinç akışı süzgecinden ulaştı̆̆ımızdan, çeviride yazarın biçeminin yansıtılması önem arz etmektedir.

\subsection{Olay örgüsü}

Henry James’in ünlü kısa romanı Ormandaki Canavar Londra'da lüks bir evde verilen öğle yemeği davetinde başlar. Hikayenin anlatıcısı davetliler arasında bulunan John Marcher adında gizemli bir adamdır. Marcher davette daha önce karşılaşmış olduğu May Bartham'ı görür. Kadına daha önceki buluşmaları ile ilgili her detayı hatırladığını söyler, ancak May adamın söylediklerini pek çok kez düzelterek ondan daha güçlü bir hafızaya sahip olduğunu gösterir. Konuşmaları sırasında May, Marcher'a uzun süredir beklediği şeyin henüz olup olmadığını sorar. Marcher kadına ne anlattığını hatırlayamadığından beklediği şeyle ilgili detayları ondan öğrenmeye çalışır. Marcher ileride başına korkunç ve tuhaf bir şey geleceğini düşünmektedir. Bu his yüzünden son derece çaresiz hisseden Marcher, May'den yanında kalıp, onunla birlikte başına gelecek olayı beklemesini ister. Kısa bir süre içerisinde samimiyetleri artar ve birlikte pek çok şey paylaşırlar. Ancak sohbetlerinin çoğu özellikle onu etkisi altına alan korku verici ve gizemli geleceği üzerinedir (Geismar, 1963: 35). May korkudan çaresiz bir durumda olan bu adama her zaman destek olur, onu yalnız bırakmaz. Çok iyi anlaşmalarına rağmen Marcher kadınla evlenmek istemez çünkü takıntılı düşüncelerinin kadını da uçuruma sürükleyeceğini düşünür. Ancak zamanla kadının da en az kendisi kadar "ormandaki canavarla" ilgilendiğini fark eder. Hatta Marcher, May’in adamın başına geleceği şeyi bildiğini düşünür. May, Marcher'a aşık olmuştur, ancak duygularını ona ifşa etmez. Kendi dertleri ve takıntılarından başka bir şey düşünmeyen Marcher kadının ona karşı hissettiklerini anlayamaz. Maxwell Geismar’ın da belirttiği gibi, ilişkileri sadece Marcher'ın kendine olan inancını korumak, artırmak, geliştirmek ve onun bilinmeyen ya da trajik kaderi üzerine kuruluydu (s. 37). Aniden May çok hastalanır ve yataktan çlkamayacak hale gelir. May'in hastalı̆̆ı Marcher'ı derinden sarsar çünkü kadının onun geleceği ile ilgili bildiği şeyleri söyleyemeden öleceğinden endişe duyar. Hatta onu bekleyen kötü kaderin kadının ölümü olabileceğini düşünüp hayal kırıklığına uğrar. Kadının onca fedakarlıklarına rağmen Marcher ölüm döşeğindeki arkadaşından hala bir şeyler öğrenme peşindedir. Bir an bile olsun adam kendi sorunlarından uzaklaşıp başkasını düşünme eyleminde bulunmaz. Kadın ölmeden önce Marcher’a "ormandaki canavarın” ne olduğunu hiçbir zaman öğrenemeyeceğini ve bu yüzden de arayışını

3 Alıntının çevirisi çalışmanın yazarına aittir.

\footnotetext{
Adres $\mid$ Address

İstanbul Medeniyet Üniversitesi, Eğitim Bilimleri Fakültesi, Türkçe İstanbul Medeniyet University, Faculty of Education Sciences, ve Sosyal Bilimler Eğitimi Bölümü, Türkce Eğitimi ABD Cevizli Turkish and Social Scinces Education, Turkish Language Teaching Kampüsü, Kartal-İstanbul/TÜRKIYE $\quad$ Education, Cevizli Campus, Kartal-İstanbul /TURKEY e-posta: editor@rumelide.com 1 e-mail: editor@rumelide.com
} 
sonlandırabileceğini söyler. Bunun üzerine adam boşluğa düşer ve amaçsız hissetmeye başlar. May öldükten sonra Marcher sık sık kadının mezarını ziyaret etmeye gider. Bir gün kadının mezarının başında hıçkırarak ağlayan bir adamla karşılaşır. İşte o an Marcher kendisinde olmayan bir şeyin farkına varır. Marcher hiçbir zaman kimse için böyle duygular beslememişti. Ayrıca Marcher kendi sorunlarıyla boğuşmaktan May’in sevgisini göremediğini onu kaybettikten sonra anlar. Bencilliği gözünü kör etmiş ve gerçekleri görmesini engellemişti. Bu gerçekle yüzleşmeye gücü olmayan Marcher mezarın üzerine doğru çöker.

\section{2. Çevirilerin ve kaynak metnin karşılaştırılması}

Kitabın yazarı ve çevirmenleri ile ilgili bilgi verdikten sonra, bu bölümde Henry James’in kısa romanı ve Türkçeye yapılmış olan iki çevirisi karşılaştırmalı olarak incelenecektir. İncelemede yayın tarihinin öncelliğine göre ilk olarak Necla Aytür'ün çevirisine (EM1), ardından Aslı Sena Özarpacı'nın çevirisine (EM2) ve son olarak da kaynak metne (KM) yer verilecektir. Seçilen örneklerle çevirmenlerin kaynak metni hangi noktalarda farklı okudukları, anladıkları ve yorumladıkları açı̆̆a çıkarılmaya çalışlacaktır. Diğer bir ifadeyle, örnekler kaynak metnin ilk çevirisi ve yeniden çevirisinin farklılaştığı noktalar üzerine yoğunlaşacaktır. Söz konusu farklıkların olası nedenlerine dair varsayımlar örneklerle birlikte sunulup, çevirmen kararlarının izi sürülecektir. James'in bu kısa romanı yazarın kendine özgü biçemiyle öne çıtı̆̆ından, incelemede biçemsel öğelere ağırlık verilip, çevirmenlerin biçemi erek metinde yansıtma konusuna verdikleri önem anlaşılmaya çalışılacaktır. Bunun yanı sıra, çevirmenlerin cümle ve sözcük düzeyindeki farklı aktarımları örneklendirilip, yadırgatıcı tercihlerin olası nedenleri üzerinde durulacaktır.

\subsection{Biçemsel özelliklerin yansıtılması}

Yazının birinci bölümünde ayrıntılı bir şekilde açıklandığı üzere James bu kısa romanında yoğun duygu ve düşünce tasvirleri, arasözler ve yinelemeli ifadeler kullanarak kendine özgü bir biçem yaratmaktadır. Özellikle ana cümlelerde özne ile yüklem arasına eklediği çeşitli ara sözler ve nitelendirmelerle okurun duruma farklı açlardan yaklaşmasını hedeflemektedir. Ancak İngilizce ve Türkçenin sözdizimsel yapısının birbirinden farklı olması bu biçemsel özelliğin çevirilere aktarımını çoğunlukla engellemektedir. Aşă̆ıdaki örnekler çevirmenlerin yazarın biçemini erek metinde nasıl yansıttıklarını göstermek amacıyla seçilmiştir.

\section{Örnek 1:}

EM1: "Konuşmaları sırasında onu irkilten sözlere neyin yol açtığı önemli değil, çünkü yeniden tanıştıktan sonra arkada kalıp ağır ağır yürürlerken kendinin gelişigüzel söylediği bir şeyden başka bir neden olmayabilir ortada. Dostları onu genç kadının kaldığı bu eve iki saat önce getirmişti; kendi kaldığı öteki evin konukları buraya öğlen yemeğine çağrılıydı; o da her zamanki gibi konuk kalabalığı arasında göze çarpmadığını sanıyordu.” (s. 137)

EM2: "Karşılaşmaları sırasında konuşmalarına yön verirken adamı şaşırtan şey, pek de mühim değildi. Tanışıklıklarını tazeledikten sonra birlikte yavaşça yürürlerken sarf ettiği sözlerdi bunu yapan. Arkadaşları tarafından bir ya da iki saat önce kadının kaldığı eve getirtilmişti. Kendisinin de aralarında bulunduğu ve aklındaki teoriyi borçlu olduğu diğer evdeki konut grubu, kendisi, her zamanki gibi kalabalıkta kaybolurken, öğle yemeğine davet edilmişti.” (s. 11)

KM: "What determined the speech that startled him in the course of their encounter scarcely matters, being probably but some words spoken by himself quite without intention--spoken as they lingered and slowly moved together after their renewal of acquaintance. He had been conveyed by friends an hour or two before to the house at which she was staying; the party of visitors at the other house, of whom he was one, and thanks to whom it was his theory, as always, that he was lost in the crowd, had been invited over to luncheon." (s. 2)

\footnotetext{
Adres | Address

İstanbul Medeniyet Üniversitesi, Eğitim Bilimleri Fakültesi, Türkçe İstanbul Medeniyet University, Faculty of Education Sciences, ve Sosyal Bilimler Eğitimi Bölümü, Türkçe Eğitimi ABD Cevizli $\quad$ Turkish and Social Scinces Education, Turkish Language Teaching Kampüsü, Kartal-İstanbul/TÜRKIYE $\quad$ Education, Cevizli Campus, Kartal-İstanbul /TURKEY e-posta: editor@rumelide.com 1 e-mail: editor@rumelide.com
} 
Romanın başlangıcından alınan bu örnekte Marcher ile May'in karşılaşma anı betimlenmektedir. Örneğin ikinci cümlesinde yazarın ara sözlerle asıl anlatmak istediği şeyi ertelediği ve böylece okurun ilgisini canlı tutmaya çalıştığı gözlemlenmektedir. EM1'de cümleler kaynak metindeki gibi iki cümle şeklinde aktarılmıştır. EM2'de ise çevirmenin cümleleri bölerek paragrafı dört cümle ile aktardığı görülmektedir. Çı kaynak metindeki ara sözler ile yan cümleleri ayrı bir cümle ile vermeyip yazarın anlatım tarzını yansıtmayı amaçlamış olabilir. Ç2 ise cümleleri bölerek erek metinde akıcı bir anlatım tarzı yaratmak istemiş olabilir. Bunun yanı sıra, kaynak metinde adamın söylediği sözler "quite without intention" ifadesiyle nitelendirilmektedir. Buna karşılık olarak EM1'de "gelişigüzel sözler" ifadesi kullanılırken, EM2'de çevirmenin silme yöntemine başvurduğu görülmektedir. Ç1 adamın sarf ettiği sözlerin önemsiz olduğunu tekrar vurgulamak amacıyla "gelişigüzel" ifadesini erek metinde yinelemiş olabilir. İlk cümlede adamın sözlerinin çok da ciddiye alınacak özellikte olmadığı ima edildiğinden, Ç2 bunu tekrar etmeyi gerekli görmemiş olabilir. Son cümlenin aktarımında da çevirmenlerin farklılık gösterdikleri açıktır. Yazar adamın kaldığı evdeki konukların öğlen yemeğine davet edildiğini söylemeden önce Marcher'ın kalabalık arasında kimsenin onu fark etmediğini sandığını ara sözlerle açılamaktadır. "and, thanks to whom it was his theory, as always, that he was lost in the crowd" şeklinde ifade edilen bu durum EM1'de "o da her zamanki gibi konuk kalabalığı arasında göze çarpmadığını sanıyordu” şeklinde, EM2'de ise "kendisinin de aralarında bulunduğu ve aklındaki teoriyi borçlu olduğu diğer evdeki konuk grubu, kendisi, her zamanki gibi kalabalıkta kaybolurken" şeklinde çevrilmiştir. Bu ara sözün çevirisinde Ç1 "teori” sözcüğünü "sanmak" fiili ile karşılarken, Ç2 kaynak metnin sözdizimsel yapısını korumak adına "teori” sözcüğünü erek metne geçirmiştir. Ancak burada anlatılmak istenen Marcher'ın benzer durumlarda kalabalık sayesinde fark edilmediğini düşünmesidir. Ç2’nin cümlesinden Marcher'ın aklındaki bu düşünceyi konukların oluşturduğu gibi bir anlam çıkmaktadır. Ayrıca Ç2’nin Marcher’ın gözden kaybolması ile konukların davet edilmesini aynı anda gerçekleşen eylemlermiş gibi aktarması okurların akıllarını karıştırabilir.

\section{Örnek 2:}

EM1: "Böylece sonunda konuşmaya başladıklarında, ocağın üstünde asılı duran portreyle tanınan bir odada dostları çıktıktan sonra yalnız kalmışlardı; işin hoş yanı ikisi de bir şey demeden arkada kalıp konuşmayı sanki aralarında önceden kararlaştırmışlardı.” (s. 139)

EM2: "Sonunda konuşmaya geldiklerinde, - önünden arkadaşlarının geçtiği odalardan birinde şöminenin önünde, dikkat çekici bir yerdi - yalnız kalmışlardı ve buranın büyüsü, konuşmadan önce dahi, konuşmak için insanlardan geri kalmayı planlamışlar etkisi vermiş olmasıydı.” (s. 13)

KM: "By the time they at last came to speech they were alone in one of the rooms - remarkable for a fine portrait over the chimney-place - out of which their friends passed, and the charm of it was that even before they spoken they had practically arranged with each other to stay behind for talk." (s. 3)

Marcher ve May sonunda odalardan birinde yalnız kalıp, konuşmaya başlarlar. Bu örnekte odanın ara sözle betimlendiği görülmektedir. EM1'de odanın özelliğini açılayan ara sözün sıfat tümceciği olarak “oda” sözcüğünden önce getirildiği gözlemlenmektedir. EM2'de çevirmen ara söz biçimini korumuş ancak ara sözün işlevini değiştirmiştir. EM2'de ara söz oda ile ilgili bilgi vermek yerine kişilerin nerede buluştuklarını açıklamaktadır. Ayrıca EM2'nin kaynak metinde olmayan "şöminenin önünde” ifadesini içerdiği görülmektedir. Ç2 bu ifadeyi karakterlerin odada konuşmaya başladıkları yeri belirginleştirmek için eklemiş olabilir. EMı'de karakterlerin konuşmaya başladıklarında odada yalnız kaldıkları kaynak metindeki düşünce akışına uygun bir şekilde aktarılmıştır. EM2'de ise karakterlerin konuşmaya başladıkları belirtildikten sonra ara sözle odanın tanımlanma şekli cümlenin doğal akışını aksatmıştır. "Dikkat çekici bir yerdi” ifadesinin odadan sonra eklenmesi cümlenin akıcılı̆̆ını aksatmıştır. Çevirilerdeki diğer farklılık ikinci cümlenin aktarımında gözlemlenmektedir. "The charm

\footnotetext{
Adres

Istanbul Medeniyet Üniversitesi, Eğitim Bilimleri Fakültesi, Türkçe İ́stanbul Medeniyet University, Faculty of Education Sciences,

ve Sosyal Bilimler Eğitimi Bölümü, Türkçe Eğitimi ABD Cevizli $\quad$ Turkish and Social Scinces Education, Turkish Language Teaching Kampüsü, Kartal-İstanbul/TÜRKIYE Education, Cevizli Campus, Kartal-İstanbul /TURKEY e-posta: editor@rumelide.com 1 e-mail: editor@rumelide.com
} 
of it” ifadesi EM1'de “işin hoş yanı”, EM2'de "buranın büyüsü” olarak aktarılmıştır. Çı'in o andaki duruma, Ç2'nin ise odanın durumuna vurgu yapmak istediği söylenebilir. Ancak dikkat çeken önemli nokta Ç2’nin kaynak metinde yer alan öğeleri eksiksiz bir biçimde erek metne aktarma eğilimidir. Bu durum yukarıdaki örnekte de olduğu gibi erek metinde "konuşmadan önce dahi, konuşmak için insanlardan geri kalmayı planlamışlar etkisi vermiş olması" gibi yadırgatıcı ifadenin oluşmasına neden olabilir.

\section{Örnek 3:}

EM1: "Üstelik Marcher’n, dile getirmeye cesaret edemediği bir düşünceyi kafasında sakladığını söyleyerek May'i suçlamasından bu yana geçen uzun süre içinde May'in bu ileri dönemin en önemli tartışmalarından birinin sona ermesinden hemen önce dile getirilen bu suçlamayı yadsımak gereğini duymaması da ilişkilerinde bundan sonra hep var olacak bir değişiklik yaratmışt." (s. 160)

EM2: "illk ve son kez olmak üzere, tüm bu süre boyunca, içinde olan, adamın kontrolündeki yalnız kadının ifade etmeye cesaret edemediği bir fikri çürütme ihtiyacı hissediyor gibi görünmediği gerçeği sayesinde, bir farklılık meydana gelmişti." (s. 39)

KM: "A difference had been made moreover, once for all, by the fact that she had all the while not appeared to feel the need of rebutting his charge of an idea within her that she didn't dare to express - a charge uttered just before one of the fullest of their later discussions ended." (s. 18)

Marcher, May'in kendisi ile ilgili gerçeği bildiğini düşünüp, onu gerçeği saklamakla suçlamaktadır. Örnekteki cümlede May'in bu suçlamayı yadsıma gereği duymadığı ve bu durumun da ilişkilerinde önemli bir değişikliğe yol açtığı belirtilmektedir. Kaynak metinde yazarın yine yoğun ve niteleme açısından zengin bir anlatım tarzı seçtiği görülmektedir. Örneğin, yazar cümlenin sonuna eklediği ara sözle kadına yapılan suçlamayı betimlemektedir. EM1'de çevirmenin kaynak metinde betimlenen "düşünce", "suçlama”, "tartışma” ve "değişiklik" sözcüklerini benzer şekilde betimlediği görülmektedir. Çı'in bu kararının temelinde kaynak metnin dilsel ve betimsel yoğunluğunu yansıtma amacı olabilir. Ancak EM2'de çevirmen "fikir" sözcüğünü nitelerken, "farklıllı" sözcüğü ile ilgili herhangi bir ayrıntı sunmamaktadır. Ayrıca EM2'de çevirmenin kaynak metindeki "charge" sözcüğünü açıkladığı, cümlenin sonunda yer alan cümleyi erek metne taşımadığı görülmektedir. Bu nedenle, silme ve eksiltme yoluna giden Ç2'nin kaynak metnin biçemsel özelliğini erek metinde birebir yansıtma amacı gütmediği sonucuna varılabilir.

\subsection{Anlam aktarımında gözlemlenen sorunlar}

Bu bölümde cümle düzeyindeki örnekler incelenip, anlamsal aktarımda gözlemlenen sorunlar ve olası nedenleri açıklanmaya çalışılacaktır.

\section{Örnek 4:}

EM1: "Ondan önce davranmak için neredeyse atıldı.” (s.139)

EM2: "Oraya kadından önce varabilmek için neredeyse atladı.” (s. 14)

KM: "He almost jumped at it to get there before her." (s.3)

Marcher ve May odada baş başa kaldıklarında daha önce nerede ve nasıl karşılaştıklarını düşünmeye başlarlar. Marcher, May’in sesini duyar duymaz geçmişe dair tüm ayrıntıları hatırlar ve kadından önce davranmak için hemen anlatmaya başlamak ister. Yukarıda verilen cümlede "to get there" ifadesi konuyu açma ya da konuşmaya başlama eylemini ima etmektedir. EM1'de çevirmen "ondan önce davranmak için neredeyse atıldı" ifadesi ile adamın vakit kaybetmeden "söze atıldığını" belirtmek

Adres

İstanbul Medeniyet Üniversitesi, Eğitim Bilimleri Fakültesi, Türkçe ve Sosyal Bilimler Eğitimi Bölümü, Türkçe Eğitimi ABD Cevizli Kampüsü, Kartal-İstanbul/TÜRKIYE e-posta: editor@rumelide.com
Address

Istanbul Medeniyet University, Faculty of Education Sciences,

Turkish and Social Scinces Education, Turkish Language Teaching

Education, Cevizli Campus, Kartal-İstanbul /TURKEY

e-mail: editor@rumelide.com 
istemiş olabilir. EM2'de ise çevirmenin kaynak metinde yer alan öğeleri erek metne bire bir aktararak, "Oraya kadından önce varabilmek için neredeyse atladı" gibi bir ifade kullandığı görülmektedir. Ç2'nin kullanmış olduğu "atlamak" fiili "söze atlama" eylemini ima ediyor olabilir. Ancak erek kültürde konuşmaya başlama durumu "söze atlamak" ile değil "söze atılmak" deyimi ile ifade edildiğinden, EM2'deki cümle okur tarafından yadırgatıcı karşılanabilir. Ayrıca EM2'deki cümlenin tamamı okunduğunda adamın sanki belli bir noktaya ulaşmak için "atlama" eylemi gerçekleştirdiği kanısına varabilir. Bu nedenle, ifadenin "hemen söze atıldı" gibi erek okurun alışkın olduğu bir ifade ile verilmesi EM2'deki aksaklığı giderebilir.

\section{Örnek 5:}

EM1: "Bu yönde işlediği günahı hemen terazinin öteki kefesi ağır basacak biçimde düzeltmeye çalışmaktan hiçbir zaman geri kalmadı̆̆ı da doğruydu.” (s. 158)

EM2: "Hem olayı öbür tarafa çevirmek için çaba göstermeden günah işlemediği doğruydu.” (s. 37)

KM: "It was true that he had never sinned in that direction without promptly enough trying to press the scales the other way." (s. 23)

Marcher bencillik etmemenin öneminin bilincindeydi ve çoğu zaman bencilliği nedeniyle yaptığı hataları telafi etmeye çalışırdı. Kaynak metinden alıntılan bu örnekte Marcher'ın hatasından hemen sonra onu telafi etmeye çalışması "promptly enough trying to press the scales the other way" şeklinde ifade edilmiştir. EMı'de bu ifadenin "terazinin öteki kefesi ağır basacak biçimde düzeltmeye hiçbir zaman geri kalmadığı” şeklinde aktarıldığı görülmektedir. Çı’in bu kararının temelinde erek metinde "terazi/adalet” kavramlarının yaygın olarak kullanılması bulunabilir. Çı, Marcher'ın yaptığı hatayı terazinin bir kefesi, hatayı telafi etmek için yaptıklarını ise terazinin diğer kefesi olarak betimlemiştir. EM2'de ise çevirmenin “olayı öbür tarafa çevirmek için çaba göstermek” ifadesini kullanmıştır. Ç2'nin bencillik kaynaklı hataları "olay” olarak tanımladığı görülmektedir. Bunun nedeni Ç2'nin bir önceki cümlede Marcher'ın sürekli bencilliğiyle yüzleşmesini "olayla iç içe kalmak” olarak ifade etmesi olabilir. Aktarımdaki diğer önemli farklılık çevirmenlerin eylemleri aktarma öncelliğinden kaynaklanmaktadır. Çı'nin çevirisinde Marcher'ın önce günah işlediği, daha sonra ise günahı telafi etmek için bir şeyler yaptığı anlaşılırken, Ç2'nin çevirisinde sanki Marcher önce hatayı telafi edecek eylemde bulunup daha sonra günah işliyormuş gibi bir anlam çıkmaktadır. Aktarımdaki bu farklılık Ç2'nin “without” edatını "olmaksızın, olmadan” şeklinde yorumlamasından kaynaklanmış olabilir.

\section{Örnek 6:}

EM1: "Onda böyle bir izlenim ilk kez uyandığı için bugün önemli bir tarih oluşturdu.” (s. 157)

EM2: “İlk izlenimi bu olduğundan bunu iyice düşünmüştü.” (s. 36)

KM: "As this was his first impression of that it quite made a date." (s. 24)

Örnekte Marcher'ın kadının kendisinden bir şeyler sakladığını anlaması ona dair “ilk izlenimi” olarak ifade edilmektedir. Bu ilk izlenimin adam üzerinde biraktığı etki "it quite made a date" cümlesi ile belirtilmiştir. EM1'de bu cümle "bugün önemli bir tarih oluşturdu" şeklinde çevrilirken, EM2'de "bunu iyice düşünmüştü” ifadesiyle aktarılmıştır. Ç1, o gününün önemini vurgulamak amacıyla "bugün tarih oluşturdu" ifadesini kullanmış olabilir. Ç2’nin ise odağa günü değil de izlenimi aldığı görülmektedir. Ancak "iyice düşünmek" ifadesi Marcher'ın o an hissettiği şaşkınlık duygusunu yansıtmada yeterli olmamaktadır.

Adres

İstanbul Medeniyet Üniversitesi, Eğitim Bilimleri Fakültesi, Türkçe ve Sosyal Bilimler Eğitimi Bölümü, Türkçe Eğitimi ABD Cevizli Kampüsü, Kartal-İstanbul/TÜRKIYE e-posta: editor@rumelide.com 


\section{Örnek 7:}

EM1: "Yaşlı teyzenin tahtından inmesi ancak ardından birçok değişiklik getiren ölümüyle oldu; özellikle Marcher'ın uzmanlaşmış dikkatine ilk bakışta, parasal bağımlılıktan dolayı gururu incindiği halde bunu belli etmeyen biri gibi görünen genç kadının yaşamında değişiklik yaptı bu ölüm.” (s.147)

EM2: Bu kişinin tahttan inişi, kadının ölümüyle gelmişti ve pek çok değişiklikle takip edilirken, Marcher'ın dikkatinin sızlayan fakat kabarmayan gururuna bağlı yaşlı kadını gördüğü genç kadında, fark edilebilir bir değişikliğe sebep olmuştu. (s. 25).

KM: "The deposition of this personage arrived but with her death, which, followed by many changes, made in particular a difference for the young woman in whom Marcher's expert attention had recognised from the first a dependant with a pride that might ache though it didn't bristle." (s.8)

Yaşlı kadının ölümüyle May'in hayatı değişmiştir. Yazar yukarıdaki örnekte hayatında değişiklikler meydana gelen May'in, Marcher tarafından nasıl görüldüğünü "dependant with a pride that might ache though it didn't bristle" sıfat tümceciği ile ifade etmektedir. Ç1 May’i tanımlarken "parasal bağımlıktan dolayı gururu incindiği halde bunu belli etmeyen biri gibi görünen genç kadın" ifadesini kullanmayı yeğlemiştir. Ç2'nin ise May'i yaşlı kadına göndermede bulunarak tanımladığı görülmektedir. EM2'de May, "sızlayan fakat kabarmayan gururuna bağlı yaşlı kadını gördüğü genç kadın” olarak betimlenmektedir. Görüldüğü üzere, Ç2’nin çevirisinde yaşlı kadının özellikleri ön plana çıartılmış ve "gururun incinmesi" durumu yaşlı kadına bağlanmıştır. Bu tür bir anlamsal kaymanın oluşmasına Ç2'nin genç kadını yaşlı kadın üzerinden tanıtması neden olmuştur. Bunun yanı sıra, erek metinde kullanılan "sızlayan fakat kabarmayan gururuna bağlı yaşlı kadın" ifadesi erek kültürde yadırgatıcı karşılanabilir.

\section{Örnek 8:}

EM1: "Sonra Marcher, yılın henüz gelen taze baharında, bir öğle sonrasında bu korkularını açık yüreklilikle dile getirdiği zaman, May ona tam kendine göre bir karşıllk verdi.” (s. 163)

EM2: "Derken ilkbaharın başladı̆̆ı, kadının, arkadaşının bu uyarıların getirdiği dürüst hainliğiyle yeni yüzleştiği o öğleden sonra geldi.” (s. 45)

KM: Then it was that, one afternoon, while the spring of the year was young and new she met all in her own way his frankest betrayal of these alarms." (s. 30).

EM1'de çevirmen, Marcher'ın korkularını dile getirmesi üzerine May'in ona kendine has bir şekilde karşllık verdiğini belirtmektedir. EM2'de ise çevirmen "alarm" sözcüğünü "uyarı", "betrayal" sözcüğünü ise "hainlik" olarak çevirerek erek metinde olumsuz bir anlam yaratmıştır. Ç1 bağlamdan faydalanarak "alarm" sözcüğünü "korku" olarak çevirmeyi yeğlemiş olabilir. Buna bağlı olarak da "betrayal” sözcüğü "dile getirmek" olarak aktarılmış olabilir. Ç2 ise kaynak metinde yer alan "betrayal of these alarms" ifadesindeki sözcüklerin anlamını aktarma amacı gütmüş olabilir. Ancak Ç2'deki asıl aksaklık cümlenin başı ile sonu arasındaki özne yüklem uyuşmazlığından kaynaklanmaktadır. “İlkbaharın başladığı" ifadesinin "geldi” yüklemi ile sonlandırılması EM2'de aykırı bir anlatımın oluşmasına neden olmuştur. Bu nedenle EM2'deki cümlenin yapısal olarak yeniden düzenlenmesi gerekmektedir. Öte yandan, EM1'de çevirmen "she met" ifadesini "karşllık vermek" olarak aktarırken, EM2'de aynı ifade "yüzleşmek" ile karşılanmıştır. Bağlamsal bilgiden yola çıkıldığında, May'in Marcher'ın söylediklerine bir tepki verdiği anlaşılmaktadır. Bu nedenle, Çı'in aktarımı kaynak metne anlamsal olarak daha yakındır. Aktarımdaki diğer bir farklılık ise çevirmenlerin odağa aldığı eylemlerdir. Ç1 ana cümlede May’in "karşllık vermesini" asıl mesele olarak sunarken, Ç2 baharın gelişini odağa almıştır.

Adres 


\subsection{Matriks normlar (silme ve eksiltmeler)}

Bu bölümde erek metne aktarılmayan cümle ya da ifadeler örneklendirilip, çevirmenlerin bu bölümleri erek metinden silmelerinin olası nedenleri açıklanacaktır.

\section{Örnek 9:}

EM1: "İşte tam bu sırada, sonradan kendi kendine düşündüğü gibi, tam dönemeç noktasında, başka her şeyden umudunu kesen genç kadın durumu kurtarmak istercesine işe el atmaya karar verdi." (s. 141)

EM2: "Derken o tam her şeyin geri teptiğini düşünürken, kadın sanki durumu kurtarmak için olayı ele aldı." (s. 16)

KM: "Then it was, just at the turn, as he afterwards made it out to himself, that, everything else failing, she herself decided to take up the case and, as it were, save the situation." (s. 6)

Yukarıdaki örnek May ve Marcher'ın baş başa kaldıkları anda konuşmadan dakikalarca bekledikleri anda kadının iletişim kurmak amacıyla adım attı̆̆ını göstermektedir. EMı'de çevirmen kaynak metindeki öğelerin tümünü anlamsal boyutuyla erek metne aktarmıştır. EM2'de ise çevirmenin "just at the turn" ve "afterwards" ifadelerini tamamıyla erek metinden çıkardı̆̆ı görülmektedir. Ç2'nin "afterwards" ifadesini çıkarırken Macher'ın düşünme eylemini ne zaman yaptığının içeriğin aktarımında çok önemli işlevi olmadığını varsayması etkili olmuş olabilir. Diğger taraftan, Ç2'nin artık kadının umudunu yitirmeye başladığını ima eden "just at the turn" ifadesini çevirmemesinin nedeni de, aynı cümlede yer alan "tam her şeyin geri teptiğini düşünürken" ifadesinin o anki durumu vurgulamaya yeteceğini düşünmesi olabilir.

\section{Örnek 10:}

EM1: "[...] slk slk May'in zihninin yalnız bir çeşit besinle beslenmesini istemediğini göstermeye çalışır; bu amaçla da ayın bir düzine akşamı birlikte orada görünmelerini sağlardı.” (s. 158)

EM2: "Ayda onlarca kez onunla orada görülmesinin nedeni adamdı." (s. 37)

KM: “[...] and it not infrequently thus happened that, to show he didn't wish her to have but one sort of food for her mind, he was the cause of her appearing there with him a dozen nights in themonth.” (s. 26)

EM1'de çevirmen kaynak metinde yer alan tüm öğeleri anlamsal boyutlarıyla erek metne aktarırken, EM2'de ana cümleden önce verilen iki ara cümlenin silindiği görülmektedir. EM2'deki paragrafın bütünü okunduğunda, Ç2'nin paragraftaki anlatımın akıcılığını bozmamak amacıyla ara sözleri silmiş olabileceği sonucuna varılabilir. Çı’in ise yazarın biçemini yansıtmak amacıyla ara sözleri erek metne aktardı̆̆ söylenebilir.

\section{Örnek 11:}

EM1: "Neydi bütün bunların anlamı? Daha doğrusu, May, onun boş yere bekleyişi, ölmesi olasılı̆̆ı, bunların tümünün getirdiği sessiz kınama, zamanın artık çok geç, yalın ve önüne geçilmez bir biçimde çok geç olduğundan başka ne anlama gelebilirdi?” (s. 17)

EM2: "Her şey ne anlama geliyordu? Artık yalnızca, karşı konulmaz biçimde geç olduğu mu?” (s. 60)

KM: "What did everything mean - what, that is, did she mean, she and her vain waiting and her probable death and the soundless admonition of it all - unless that, at this time of day, it was simply, it was overwhelmingly too late?" (40).

\footnotetext{
Adres $\mid$ Address

İstanbul Medeniyet Üniversitesi, Eğitim Bilimleri Fakültesi, Türkçe İstanbul Medeniyet University, Faculty of Education Sciences, ve Sosyal Bilimler Eğitimi Bölümü, Türkçe Eğitimi ABD Cevizli $\quad$ Turkish and Social Scinces Education, Turkish Language Teaching Kampüsü, Kartal-İstanbul/TÜRKIYE $\quad$ Education, Cevizli Campus, Kartal-İstanbul /TURKEY e-posta: editor@rumelide.com 1 e-mail: editor@rumelide.com
} 
Bu örnek Marcher’n May’in hastalanması ve yatağa düşmesi sonrası hayatın anlamını sorguladığı bölümden alınmıştır. Kadının çok kısa bir süre içinde ölüm döşeğine düşmesi Marcher’ı derinden sarsmıştı. Kaynak metinde yazarın bir soru sorup, daha sonra durumla ilgili detayları ara sözlerle ayrıntılandırdığı görülmektedir. EMı'de çevirmen kaynak metinde yer alan bütün öğeleri anlamsal boyutlarıyla erek metne geçirme eğilimi göstermiştir. Bunun nedeni, Çı’in kaynak metin yazarının biçemini yansıtma çabası göstermesi olabilir. Çı de yazar gibi belli bir konu ile ilgili farklı bakış açılarını erek okura iletmek istemiş olabilir. EM2'de ise çevirmenin durumla ilgili detayları erek metne aktarmama eğiliminde olduğu gözlemlenmektedir. Ç2 kaynak metindeki ara cümle ve sözleri erek metne aktarmamıştır. Bu nedenle, Ç2'in yazarın biçemini erek metinde yansıtma amacı gütmediği sonucuna varllabilir.

\title{
2.4. Sözcük düzeyi aktarımlar
}

Çalışmanın bu bölümünde çevirmenlerin sözcük seçimlerindeki farklılıklar açığa çıkarılıp, bu farklı kullanımların olası nedenleri tartışılacaktır.

\section{Örnek 12:}

\begin{abstract}
KM: "He hadn't disturbed people with the queerness of their having to know a haunted man,though he had had moments of rather special temptation on hearing them say they were forsooth

"unsettled." If they were as unsettled as he was--he who had never been settled for an hour in his life--they would know what it meant." (s. 9)
\end{abstract}

EM1: "Özellikle bir türlü durup oturamadıklarını söyleyen kimseleri dinlerken bazen konuşmaya can attığı halde konuşmamış, insanları cin çarpmış birini tanımak garipliliğiyle karşı karşıya bırakarak tedirgin etmemişti. Kendisi gibi yaşamlarında bir saat için bile "durup oturmak" nedir bilmeseler, işte o zaman anlarlardı bunun ne demek olduğunu.” (s. 149)

EM2: “İnsanların gerçekten 'kararsız' olduklarını söylediklerini duyarak baştan çıktığı zamanlar olmasına karşın, onları rahatsız bir adamı tanıdıkları konusundaki gariplik rahatsız etmezdi. Eğer onun kadar kararsız olsalar bunun ne anlama geldiğini bilirlerdi.” (s. 27)

Bu örnekte yazar Marcher’n takıntıları yüzünden bir türlü düzen kuramadığını anlatmaya çalışmakta ve bu amaçla Marcher'ı "unsettled" bir kişi olarak tanımlamaktadır. EM1'de "unsettled" ifadesinin "durup oturamamak", EM2'de ise "kararsız" ifadeleriyle karşlandı̆̆ı görülmektedir. Ç1’in "durup oturamamak" gibi bir ifadeyi tercih etmesinin bu ifadenin hem anlamsal olarak "settled" ifadesini karşıladığı hem de ikinci cümlede yer alan "settled for an hour" ifadesine uygun düştüğü düşüncesi olabilir. Yazarın "settled" ifadesini bir saatlik bir eylemle örtüştürmesi Çı'in böyle bir tercih yapmasında etkili olmuş olabilir. Diğer bir deyişle, "durup oturamamak" ifadesinin hem adamın hayatında belli bir düzen oturtamamasını hem de hayatında bir saat bile oturamamış olmasını karşılayacağı düşünülmüş olabilir. Ç2 ise adamın içinde bulunduğu durumu "kararsız" olarak nitelendirmeyi yeğlemiştir. Ç2'nin bu kararının temelinde "settled" ifadesinin "kararsız" anlamına gelmesi yatıyor olabilir. Ç2 bu sözcük seçimiyle, Marcher’a kitabın genelinde vurgulanan özellikten farklı bir özellik atfetmiştir. Bu nedenle, Ç2’nin bağlamdan kopuk bir şekilde ifadeyi yorumladığı sonucuna varabiliriz.

\section{Örnek 13:}

EM1: Gerçek durumunda eksikliğini duydukları şey işte o zaman tamamlanacaktı. (s. 141).

EM2: İşte o zaman gösterilerinde yoksun oldukları malzemeyi elde etmiş olacaklardı. (s. 15)

KM: "Then they would be in possession of the something or other that their actual show seemed to lack" (s. 5)

\footnotetext{
Adres $\mid$ Address

İstanbul Medeniyet Üniversitesi, Eğitim Bilimleri Fakültesi, Türkçe ve Sosyal Bilimler Eğitimi Bölümü, Türkçe Eğitimi ABD Cevizli $\quad$ Turkish and Social Scinces Education, Turkish Language Teaching Kampüsü, Kartal-İstanbul/TÜRKIYE $\quad$ Education, Cevizli Campus, Kartal-İstanbul /TURKEY e-posta: editor@rumelide.com 1 e-mail: editor@rumelide.com
} 
Marcher daha önce May ile neden özel bir ortam ya da durumda tanışmadıklarına üzülmektedir. Ona göre geçmişte özel bir an paylaşmış olsalardı şimdi ikinci kez bir araya geldiklerinde bazı şeyler çok daha farklı olabilirdi. Yukarıda verilen cümle böyle bir düşünceden doğmuş bir ifadedir. Cümlede geçen "show" sözcüğünün erek metinlerde farklı bir şekilde karşılandığı görülmektedir. EM1'de "durum" ifadesi kullanılırken, EM2'de "gösteri" ifadesi kullanılmıştır. Ç1 "durum" ifadesiyle Marcher'ın hissettiklerini anlatmaya çalışmış olabilir. Ç2 ise kaynak metindeki ifadeyi erek metne "gösteri" olarak aktararak farklı bir resim çizmek istemiş olabilir. Ancak kaynak metinden örneklendirilen bu kısımda karakterlerin "gösteri” yapma amaçlı herhangi bir şey sergilemeleri söz konusu değildir. Bu nedenle, Ç2’nin kaynak metindeki sözcüğün sözlük anlamına bağlı kalma nedeniyle böyle bir aktarım yapmış olabileceği ve bu kullanımın da erek okur tarafından "yadırgatıcı" bir ifade olarak yorumlanabileceği söylenebilir.

\section{Örnek 14:}

EM1: "Ama yürekli adam neden korktuğunu ve korkmadığını bilmez mi? Görüyorsun ben bunu biliyorum. Ama adını koyamıyorum. Bütün bildiğim tehlikede olduğum.” (s. 157)

EM2: "Fakat cesur adam neden korktuğunu... Ya da korkmadığını bilmez mi? Görüyorsun ya ben bunu biliyorum. Buna bir isim veremiyorum. Yalnızca teşhir edildiğini biliyorum.” (s. 36)

KM: "But doesn't the man of courage know what he's afraid of - or not afraid of? I don't know that, you see. I can't name it. I only know I'm exposed.” (s. 21)

Yazar "to be exposed” ifadesi ile Marcher'ın ileride başına geleceği şeyle ilgili hissettiği duyguyu ifade etmektedir. Bağlamsal bilgilerden anlaşılacağı üzere Marcher başına gelecek şeyin korkunç ve tehlikeli bir şey olduğunu iddia etmektedir. EM1'de "tehlikeli olmak" ile karşlanan ifade EM2'de "teşhir edilmek" ile karşılanmıştır. Çı bağlamsal bilgilerden yola çıkarak "tehlikede olmak" ifadesini kullanmış olabilir. Ç2'nin "to expose" fiilin anlamlarından biri olan "sergilemek, teşhir etmek" anlamını temel aldığı söylenebilir. Ancak bu örnekte Marcher’ın "sergilenmesi ya da teşhir edilmesi” ima edilmediğinden, Ç2’nin aktarımı erek metinde yadırgatıcı bir ifadeye yol açmıştır.

\section{Örnek 15:}

EM1: "Zorunlu gün gelip de arkadaşı ona kanında köklü bir düzensizlikten kuşkulandığını açıklamak zorunda kaldığında, Marcher, üzerinde bir değişikliğin gölgesini, büyük bir sarsıntının soğukluğunu duydu.” (s. 161)

"EM2: "Olması gerektiği gibi o gün gelip arkadaşı ona kanındaki önemli bir bozukluk nedeniyle duyduğu korkuyu itiraf ettiğinde, bir şekilde, değissikliğin gölgesini ve bir takozun soğukluğunu hissetti." (s. 40)

KM: "When the day came, as come it had to, that his friend confessed to him her fear of a deep disorder in her blood, he felt somehow the shadow of a change and the chil of a shock." (s. 572)

Bu örnekte Marcher’nn arkadaşının hastalı̆̆ını öğrenmesi üzerine hissettikleri "the shadow of a change and the chil of a shock" ifadeleri ile betimlenmektedir. EM1'de "the chil of a shock" ifadesi "sarsintının soğukluğu” ile karşlanırken, EM2'de aynı ifade "takozun soğukluğu” ile karşlanmıştır. Çevirmenlerin "shock" sözcügünün aktarımında farklı sözcükleri tercih ettikleri görülmektedir. Ç1 "sarsıntı" ifadesini kullanırken, Ç2 "takoz" ifadesini kullanmıştır. Çı, "sarsıntı” sözcüğüyle Marcher’ın yaşadığı üzüntüyü vurgulamayı amaçlamış olabilir. Ancak Ç2'nin neden "takoz" sözcüğünü seçtiğine dair tahminde bulunmak pek kolay değildir. "Shock” sözcügünün "takoz” anlamı bulunmakla birlikte Ç2'nin üzülme duygusunu "takozun” soğukluğuna benzetme nedeni bağlamdan çıkarılamamaktadır.

Adres

İstanbul Medeniyet Üniversitesi, Eğitim Bilimleri Fakültesi, Türkçe ve Sosyal Bilimler Eğitimi Bölümü, Türkce Eğitimi ABD Cevizli Kampüsü, Kartal-İstanbul/TÜRKIYE e-posta: editor@rumelide.com 


\section{Sonuç ve değerlendirmeler}

Bu çalışmada Henry James’in “The Beast in the Jungle” adlı kısa romanın Türkçe’ye yapılan iki çevirisi farklılıklardan yola çıkılarak incelenmiş ve çevirmen davranışları betimlenmeye çalışılmıştır. İlk olarak 1988 yılında çevirisi yapılan bu eserin, 2015 yılında farklı bir çevirisinin üretilmesi çalışmanın yeniden çeviri bağlamında da incelenmesini gerekli kılmıştır. İlk çevirisinin hala yayın dünyasında varlığını sürdürmesi, yeniden çeviri olgusunun büyük ihtimalle yayınevi politikası sonucu gerçekleştirildiğine işaret etmektedir. Nitekim söz konusu yayınevinin James’ten beş farklı eserin çevirisini yayımlaması tahminimizi doğrular niteliktedir.

Çevirmenlerin çevirmen davranışlarını karşılaştırdığımızda, farklı özelliklerin öne çıktığını görmek mümkündür. Çı’in çevirisinde kaynak metin yazarını temsil etme amacı taşıdığı görülmektedir. Diğer bir ifadeyle, Ç2 kaynak metnin biçemsel özelliklerini erek metinde yansıtmaya çalışmıştır. Bu amaçla, Ç2'nin kaynak metinde yer alan öğeleri, özellikle örnek (9), (10), (11) gözlemlendiği üzere, erek metne anlamsal boyutlarıyla aktarmıştır. Bunun yanı sıra Ç1, yazarın yoğun betimleme içeren anlatım biçemini erek metne taşımaya özen göstermiştir. Ç1'in bu eğilimi özellikle (1) ve (3) nolu örneklerde açığa çıkmaktadır. Çı'in erek metinde kullandığı betimlemelerde erek okurun beklentilerini göz önünde bulundurduğu incelenen örneklerin tümünde gözlemlenmiştir. Çı’in aktarımlarında erek okuru şaşırtacak "yardırgatıcı" ifadelere ve hatalı yorumlamalara rastlanmamıştır. Çı'nin diğer öne çıkan özelliği sözcüklerin aktarımında izlediği yöntemdir. Ç1, kaynak metinde yer alan sözcükleri metnin bağlamsal özelliklerine uygun bir şekilde aktarmıştır. Çı'in bu eğilimi özellikle (7), (8), (12), (13), (14), (15) nolu örneklerde görülmektedir.

Ç2'nin göze çarpan en belirgin çevirmen davranışı yazarın biçemini erek metinde yansıtma çabası göstermemesidir. Ç2 örnek (1)'de görüldüŭü gibi cümleleri bölerek erek metinde anlatımın yoğunluğunu azaltmıştır. Ayrıca Çı'in metnin bazı bölümlerinde ara cümleleri tamamen sildiği gözlemlenmektedir. (3), (9), (10), (11) no'lu örneklerde Ç1 ara sözleri silerek durumu daha yalın bir şekilde aktarmayı yeğlemiştir. Çı’in öne çıan diğer bir özelliği kaynak metindeki sözcükleri bağlamdan kopuk ve sözlük anlamlarına bağlı olarak aktarma eğilimidir. Ç2, özellikle (7), (8), (12), (13), (14), (15) no'lu örneklerde sözcükleri bağlamdan bağımsız bir şekilde erek metne taşımış ve bu nedenle de erek metinde "yadırgatıcı" ifadelerin kullanılmasına yol açmıştır. Bunun yanı sıra, (1), (2), (3) no'lu örneklerde Ç2’nin kaynak metindeki sözcüklere bağlı kalma eğilimi nedeniyle erek metinde yadırgatıcı ifadeler kullandığı görülmektedir. Ayrıca (4), (5), (6), (7) no’lu örneklerdeki gibi Ç2 zaman zaman kaynak metni yanlış yorumlamış ve erek metinde anlatım bozukluğuna yol açmıştır.

Ç1 ve Ç2'nin çevirmen davranışlarına dair elde edilmiş olan sonuçlar çevirmenlerin genel çeviri yöntemleriyle uygunluk göstermektedir. Selim İleri tarafından kaleme alınan bir eleştiri yazısında Çı'in James’in üslubuna erek dilde eşdeğerler yarattığı belirtilmektedir ${ }^{4}$. Çı'in farklı bir çevirisinin incelendiği yüksek lisans tezinde ise çevirmenin öncül normunun "yeterliliğe" daha yakın olduğu sonucuna varılmıştır5. Öte yandan, Ç2’nin Türkçe'ye yapmış olduğu Ağaç İşçileri (2006, Altın Bilek) çevirisi incelendiğinde çevirmenin bu çalışmada saptanmış olan çevirmen davranışlarına benzer davranışlar sergilediği görülmüştür.

Biçem, anlam ve sözcük düzeyinde yapılan karşılaştırmalar sonucu çevirmenlerin kaynak metni farklı şekilde okudukları ve yorumladıkları sonucuna varılabilir. Çı'nin yazarın biçemini erek metinde

Bkz. http://www.radikal.com.tr/kitap/henry-jamesin-bakis-acisi-920593/

bkz. http://www.sbe.deu.edu.tr/public/document/gururSayfamiz/12.pdf

Adres

İstanbul Medeniyet Üniversitesi, Eğitim Bilimleri Fakültesi, Türkçe ve Sosyal Bilimler Eğitimi Bölümü, Türkçe Eğitimi ABD Cevizli Kampüsü, Kartal-İstanbul/TÜRKIYY e-posta: editor@rumelide.com
Address

İstanbul Medeniyet University, Faculty of Education Sciences,

Turkish and Social Scinces Education, Turkish Language Teaching

Education, Cevizli Campus, Kartal-İstanbul /TURKEY

e-mail: editor@rumelide.com 
yansıtma amacı taşırken, Ç2'nin böyle bir çabası bulunmamaktadır. Ç2'nin çeviri sürecinde kaynak metnin sözdizimsel yapısına bağlı kalma eğilimi nedeniyle erek metnin bazı bölümlerinde yadırgatıcı ifadeler oluşmuştur. Bunun yanı sıra, Ç2'nin kimi zaman kaynak metni yanlış yorumlaması erek metinde anlatım bozukluklarına yol açmıştır. Bu nedenle, yapılan inceleme sonucunda EMı'nin kaynak metnin biçemini daha iyi yansıttığını ve EM2'nin tekrar gözden geçirilmesi gerektiğini söyleyebiliriz. Çalışmayı yeniden çeviri bağlamında değerlendirdiğimizde ise Ç2'nin birinci çeviriyi okumadığı sonucuna varabiliriz. Öte yandan, romanın yeniden çevirisinin kaynak metni ya da yazarı daha "iyi” temsil etme amacıyla yapılmadığı ortadadır.

Son olarak, kaynak odaklı kuralcı yaklaşımların aksine salt kaynak metin-erek metin karşılaştırmasına dayanmayan, metin-ötesi unsurları da dikkate alan bu çalışma edebiyat çevirisi incelemelerinde eleştirel bilincin oluşmasına katkıda bulunacaktır. Örnek inceleme aşamasında benimsenen betimleyici yaklaşım ve örneklerin yorumlanmasında kullanılan "üslup" nesnel bir edebiyat çevirisi eleştirisinin nasıl yapılacağına örnek teşkil etmektedir. Bu tür çalışmaların çoğalması edebiyat çevirisi eleştirilerinin bilimsel temellere oturtulmasını sağlayacaktır.

\section{Kaynakça}

Aytür, Necla (1988). Ormandaki Canavar. Yürek Burgusu. İstanbul: Adam.

Berman, Antoine (1990). La retraduction çömme espace de traduction. Palimpsestes Retraduire,4, Paris: Presses de la Sorbonne Nouvelle.

Ece, Ayşe (2010). Edebiyat çevirisinin ve çevirmenin izinde. İstanbul: Sel.

Geismar, Maxwell (1963). Henry James: The Beast in the Jungle: Nineteenth-Century fiction, 18 (1), California: University of California Press.

Goodheart, Eugene (2003). What may knew in 'The Beast in the Jungle”. The Sewanee Review, 111 (1), Baltimore: The Johns Hopkins University Press.

Henderson, Andrea (2004). Henry James. Encylopedia of World Biography, 2 (8), Detroit: Gale.

James, Henry (1993). The Beast in the Jungle and other stories. Dover: Dover Publications.

James, Henry (2000). What Maisie Knew. United Kingdom: Wordsworth Editions Ltd.

Özarpacı, Aslı S. (2015). Ormandaki Canavar. İstanbul: Altın Bilek.

Patrick, Walton R. (1967). Poetic style in the contemporary short story. College Composition and Communication, 18 (2).

Venuti, Lawrence (2013). Translation changes everything: Theory and practice. London \& New York: Routledge. 